- News \& Views •

\title{
Revisiting the Concentration Observations and Source Apportionment of Atmospheric Ammonia
}

\author{
Yuepeng PAN ${ }^{*} 1,2,3$, Mengna GU ${ }^{1,2}$, Yuexin $\mathrm{HE}^{1,2}$, Dianming WU ${ }^{4}$, Chunyan $\mathrm{LIU}^{1,2}$, Linlin SONG ${ }^{2,5}$, \\ Shili TIAN ${ }^{1}$, Xuemei LÜ1 ${ }^{1}$, Yang SUN 1 , Tao SONG ${ }^{1}$, Wendell W. WALTERS ${ }^{6,7}$, Xuejun LIU ${ }^{8}$, \\ Nicholas A. MARTIN ${ }^{9}$, Qianqian ZHANG $^{10}$, Yunting FANG $^{2,5,11}$, \\ Valerio FERRACCI ${ }^{12}$, and Yuesi WANG ${ }^{1,2,3}$ \\ ${ }^{1}$ State Key Laboratory of Atmospheric Boundary Layer Physics and Atmospheric Chemistry, \\ Institute of Atmospheric Physics, Chinese Academy of Sciences, Beijing 100029, China \\ ${ }^{2}$ University of Chinese Academy of Sciences, Beijing 100049, China \\ ${ }^{3}$ Center for Excellence in Urban Atmospheric Environment, Institute of Urban Environment, \\ Chinese Academy of Sciences, Xiamen 361021, China \\ ${ }^{4}$ Key Laboratory of Geographic Information Sciences, Ministry of Education, School of Geographic Sciences, \\ East China Normal University, Shanghai 200241, China \\ ${ }^{5}$ CAS Key Laboratory of Forest Ecology and Management, Institute of Applied Ecology, \\ Chinese Academy of Sciences, Shenyang 110016, China \\ ${ }^{6}$ Department of Earth, Environmental, and Planetary Sciences, Brown University, Providence, RI 02912, USA \\ ${ }^{7}$ Institute at Brown for Environment and Society, Brown University, Providence, RI 02912, USA \\ ${ }^{8}$ College of Resources and Environmental Sciences, China Agricultural University, Beijing 100193, China \\ ${ }^{9}$ National Physical Laboratory, Air Quality and Aerosol Metrology Group, Environment Department, \\ Hampton Road, Teddington, Middlesex, TW11 0LW, UK \\ ${ }^{10}$ National Satellite Meteorological Center, China Meteorological Administration, Beijing, 100081, China \\ ${ }^{11}$ Key Laboratory of Stable Isotope Techniques and Applications, Shenyang 110016, China \\ ${ }^{12}$ Centre for Environmental and Agricultural Informatics, Cranfield University, College Road, MK43 OAL, UK
}

(Received 20 April 2020; revised 28 May 2020; accepted 15 June 2020)

Citation: Pan, Y. P., and Coauthors, 2020: Revisiting the concentration observations and source apportionment of atmospheric ammonia. Adv. Atmos. Sci., 37(9), 933-938, https://doi.org/10.1007/s00376-020-2111-2.

While China's Air Pollution Prevention and Control Action Plan on particulate matter since 2013 has reduced sulfate significantly, aerosol ammonium nitrate remains high in East China. As the high nitrate abundances are strongly linked with ammonia, reducing ammonia emissions is becoming increasingly important to improve the air quality of China. Although satellite data provide evidence of substantial increases in atmospheric ammonia concentrations over major agricultural regions, long-term surface observation of ammonia concentrations are sparse. In addition, there is still no consensus on whether agricultural or non-agricultural emissions dominate the urban ammonia budget. Identifying the ammonia source by nitrogen isotope helps in designing a mitigation strategy for policymakers, but existing methods have not been well validated. Revisiting the concentration measurements and identifying source apportionment of atmospheric ammonia is thus an essential step towards reducing ammonia emissions.

\section{The need for ammonia monitoring in the atmosphere}

Ammonia $\left(\mathrm{NH}_{3}\right)$ is the most abundant alkaline gas in the atmosphere. While $\mathrm{NH}_{3}$ has a beneficial role in buffering acid rain (Wang et al., 2012), after deposition it can detrimentally affect Earth's ecosystems through soil acidification, water

\footnotetext{
* Corresponding author: Yuepeng PAN

Email: panyuepeng@mail.iap.ac.cn
} 
eutrophication, and biodiversity loss (Liu et al., 2019). The overabundance of $\mathrm{NH}_{3}$ in the lower atmosphere is suggested to promote the formation of secondary ammoniated aerosol particles (Wang et al., 2016), with significant impacts on visibility deterioration and human health (An et al., 2019). Recently, $\mathrm{NH}_{3}$ and ammonium nitrate particles were also found in the upper troposphere during the Asian monsoon and play a hitherto neglected role in ice cloud formation and aerosol indirect radiative forcing (Höpfner et al., 2019). However, the severe lack of $\mathrm{NH}_{3}$ measurements with sufficient spatial and temporal coverage is currently a barrier to understanding the vital role of $\mathrm{NH}_{3}$ in air pollution, ecosystem protection, and climate change. It has resulted in unclear regulatory guidelines for mitigating these effects (Pan et al., 2020b).

\section{Current status of ammonia observations and limitations}

Anthropogenic emissions of $\mathrm{NH}_{3}$ in China are more significant than the total emissions of the U.S. and the European Union (Liu et al., 2019). To date, there is still no national $\mathrm{NH}_{3}$ concentration monitoring network operated by the Chinese government. Following the guidelines of the National Atmospheric Deposition Program in the U.S., the Institute of Atmospheric Physics, Chinese Academy of Sciences, established a Regional Atmospheric Deposition Observation Network in the North China Plain (READ-NCP). This network, including 10 sites covering different land-use types, started monitoring $\mathrm{NH}_{3}$ concentrations in 2007, and has also obtained significant results with respect to the atmospheric deposition of nitrogen, carbon, sulfate, and metals. Based on the observations of READ-NCP from 2008 to 2010, $\mathrm{NH}_{3}$ was found to be a significant contributor to nitrogen deposition in this region (Pan et al., 2012). Thus, clarification of $\mathrm{NH}_{3}$ levels in China can aid policymakers in the protection of ecosystems from excess nitrogen deposition. Due to the lack of data, however, the whole picture of $\mathrm{NH}_{3}$ distribution in China was poorly understood. In 2015, READ-NCP was extended to a spatially dense and costefficient network focusing on $\mathrm{NH}_{3}$ observations in China (AMoN-China) (Pan et al., 2018). The system currently consists of approximately 100 sites, which is similar to that of the U.S. AMoN (Fig. 1). While the $\mathrm{NH}_{3}$ concentration was relatively low in the U.S., there is an increasing importance of deposition of reduced nitrogen due to the significant reduction in oxidized nitrogen (Li et al., 2016).

Besides AMoN in China (Pan et al., 2018) and the U.S. (http://nadp.slh.wisc.edu/AMoN), the monitoring of surface $\mathrm{NH}_{3}$ is also conducted by other networks (Fig. 1), e.g., EANET (The Acid Deposition Monitoring Network in East Asia; https://www.eanet.asia), EMEP (the Co-operative Programme for Monitoring and Evaluation of the Long-Range Transmission of Air Pollutants; http://ebas.nilu.no/Default.aspx) and the IDAF (IGAC-DEBITS-AFRICA) program for African ecosystems (Adon et al., 2010). Most of these networks employed a cost-effective approach by using passive samplers, including ALPHA, Analyst, Radiello, and Ogawa, which have advantages in characterizing the spatial distribution and long-term trends of $\mathrm{NH}_{3}$. However, the accuracy of these passive $\mathrm{NH}_{3}$ sampling techniques is not well validated in the field, which represents one of the biggest challenges in $\mathrm{NH}_{3}$ monitoring (Martin et al., 2019). For example, it is reported that the $\mathrm{NH}_{3}$ concentrations collected by Radiello passive samplers are approximately $40 \%$ lower than the denuder-based reference method (Puchalski et al., 2011). The low $\mathrm{NH}_{3}$ concentration bias in the passive collection samplers was suggested to be the result of inaccurate effective sampling rates due to incorrect mass transfer correction factors for the environmental conditions (Pan et al., 2020a). Thus, questions remain as to whether the $\mathrm{NH}_{3}$ concentrations from different networks can be directly compared if they employed different passive samplers. Concurrent measurements of the passive samplers used in various networks are thus further needed, with a collocated reference method, e.g., annular denuders and continuous real-time instruments employing the wet chemistry technique (von Bobrutzki et al., 2010; Martin et al., 2019; Pan et al., 2020a).

\section{Debate on ammonia sources in the urban atmosphere}

The need for source apportionment has increased in recent years as atmospheric $\mathrm{NH}_{3}$ concentrations and deposition fluxes have shown little change or even increased following more stringent air pollutant controls (Liu et al., 2018). Longterm satellite observation from the Atmospheric Infrared Sounder (AIRS) aboard NASA's Aqua satellite also implied that $\mathrm{NH}_{3}$ levels over agricultural regions had experienced significant increasing trends between 2002 and 2013, with an annual increase rate of $2.6 \%, 1.8 \%$ and $2.3 \%$ in the U.S., the European Union, and China, respectively (Warner et al., 2017). The increment of atmospheric $\mathrm{NH}_{3}$ concentrations tended to continue between 2013 and 2017, as observed from space with the Cross-track Infrared Sounder (CrIS) (Shephard et al., 2020). While agricultural activities (fertilization and livestock volatilization) are known to dominate the emissions of $\mathrm{NH}_{3}$, accounting for over $60 \%$ and $80 \%$ of the global and Asian inventory (Bouwman et al., 1997; Huang et al., 2012), non-agricultural sources have been suggested as a major $\mathrm{NH}_{3}$ source at the urban scale (Felix et al., 2014; Pan et al., 2016; Sun et al., 2017; Chang et al., 2019; Walters et al., 2020a).

Ammonia emissions in developing cities are especially important because of their high emissions ratios to $\mathrm{CO}_{2}$ and rapidly expanding vehicle fleets (Sun et al., 2017). For example, vehicular emissions were found to be a critical $\mathrm{NH}_{3}$ source in urban Beijing (Ianniello et al., 2010; Meng et al., 2011). Industrial $\mathrm{NH}_{3}$ emissions, rather than those from vehicles, were also identified in the megacity of Shanghai (Wang et al., 2015). However, in contrast to previous results, Teng et al. (2017) 

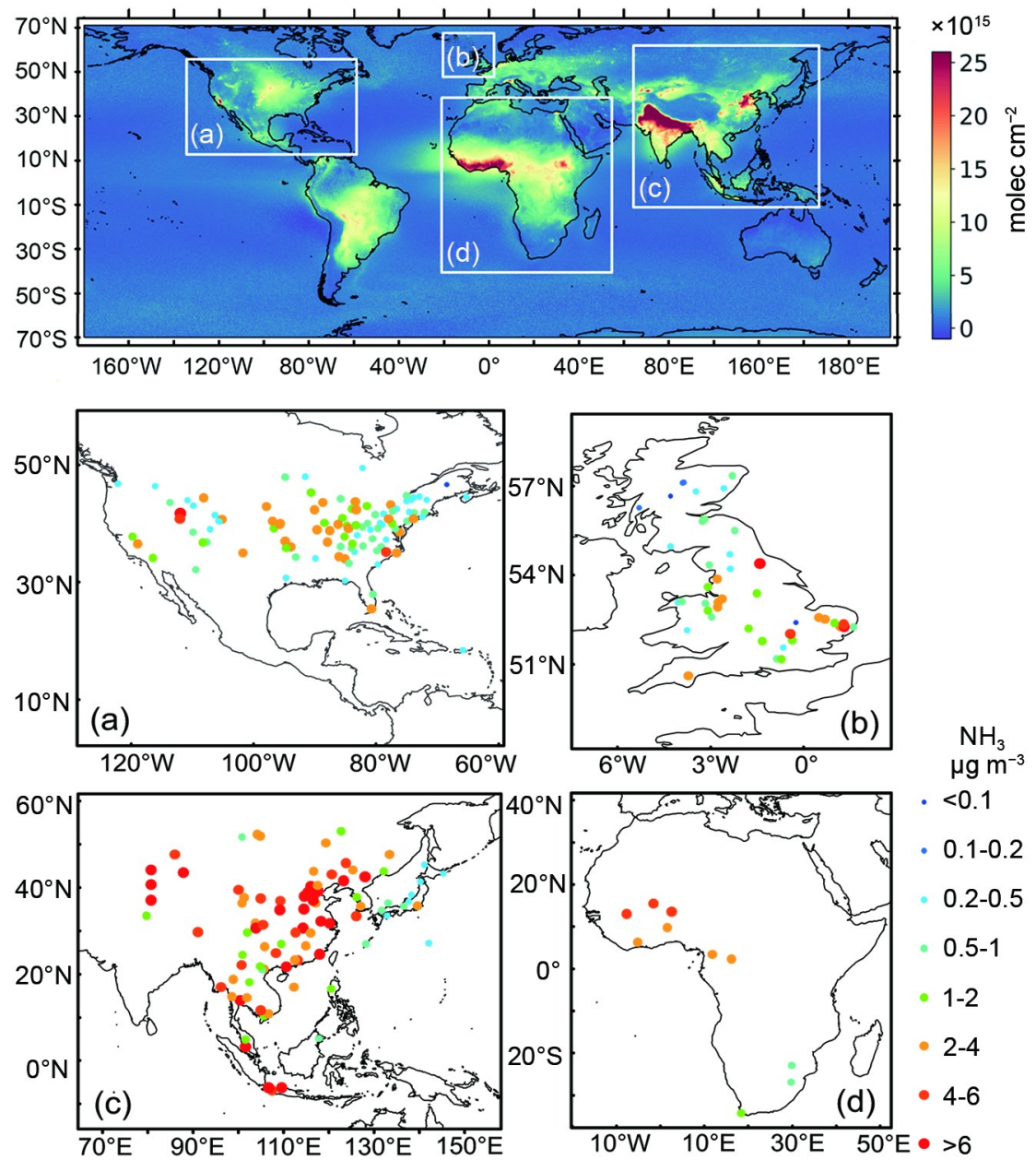

Fig. 1. Surface ammonia concentrations during 2015-16 observed by AMoN in (a) the U.S (http://nadp.slh.wisc.edu/AMoN/), (b) the UK (https://uk-air.defra.gov.uk/), and (c) East Asia (https://www.eanet.asia) including China (Pan et al., 2018). (d) Long-term surface measurements of ammonia in Africa within the framework of the IDAF (IGAC-DEBITSAFRICA) program (mean values from 1998 to 2007) (Adon et al., 2010). Global ammonia morning column measurements (2008-16) observed from space by IASI are also shown (https://doi.pangaea.de/10.1594/PANGAEA.894736).

suggested that urban green spaces and evaporation of deposited $\mathrm{NH}_{x}\left(\mathrm{NH}_{3}+\mathrm{NH}_{4}{ }^{+}\right)$on wet surfaces, rather than traffic and agricultural emissions, were the primary source for $\mathrm{NH}_{3}$ in an urban environment during winter in NCP. Thus, there is still no consensus on whether these emissions are among the major sources of urban atmospheric $\mathrm{NH}_{3}$. Currently, the rapid development of isotope techniques is promising (Liu et al., 2014) and may provide scientists and policymakers with a more robust methodology and reliable evidence to track atmospheric $\mathrm{NH}_{3}$ sources (Felix et al., 2014; Pan et al., 2016; Chang et al., 2019; Walters et al., 2020a).

\section{Constraining ammonia sources utilizing nitrogen isotopes}

The use of nitrogen isotopic composition of $\mathrm{NH}_{3}\left(\delta^{15} \mathrm{~N}-\mathrm{NH}_{3}\right)$ as a fingerprint identification of $\mathrm{NH}_{3}$ emissions sources requires distinguishable isotopic signatures (Felix et al., 2013). While this technique has been widely used in Chinese cities, e.g., Beijing (Pan et al., 2016; Zhang et al., 2020) and Shanghai (Chang et al., 2019), considerable uncertainties remain in characterizing the endmembers. In particular, current collection methods are almost exclusively based on passive samplers, which have not been verified for their suitability to characterize $\delta^{15} \mathrm{~N}-\mathrm{NH}_{3}$ accurately. Recently, Walters and Hastings (2018) validated an active sampling collection technique using an acid-coated honeycomb denuder to characterize $\delta^{15} \mathrm{~N}$ $\mathrm{NH}_{3}$ under a variety of laboratory-controlled conditions as well as under field conditions. As a reference to this new verified method, Walters et al. (2020a) also found a substantial low bias of $15 \%$ in the ALPHA passive sampler in characterizing $\delta^{15} \mathrm{~N}-\mathrm{NH}_{3}$ from traffic plumes. Such a low bias of passive samplers in characterizing $\delta^{15} \mathrm{~N}^{-\mathrm{NH}_{3}}$ was also confirmed in field observations in urban Beijing by Pan et al. (2020a). Thus, previous source apportionment needs to be reevaluated if 
using an inventory of $\delta^{15} \mathrm{~N}-\mathrm{NH}_{3}$ based on passive samplers, especially the ALPHA sampler.

To evaluate the potential influences of the low bias of $\delta^{15} \mathrm{~N}-\mathrm{NH}_{3}$ by passive samplers, we revisited the sources of atmospheric $\mathrm{NH}_{3}$ in urban Beijing using a Bayesian isotope mixing model (SIAR, Stable Isotope Analysis in R) (Kendall et al., 2007). Two scenarios were performed based on an isotopic inventory with and without correction for the passive collection $\delta^{15} \mathrm{~N}^{-\mathrm{NH}_{3}}$ bias (Fig. 2). Accordingly, the model was run with $\delta^{15} \mathrm{~N}-\mathrm{NH}_{3}$ values of $-18.2 \%$ (corrected) and $-33.2 \%$ (original uncorrected) as input for ambient samples. The latter value represented an annual mean $\delta^{15} \mathrm{~N}-\mathrm{NH}_{3}$ value in urban Beijing based on a year-round and weekly collection by the passive ALPHA sampler (Zhang et al., 2020).

Figure 3a demonstrates that non-agricultural sources contributed only $57 \%$ of $\mathrm{NH}_{3}$ using the inventory without correction (Fig. 2), which is lower than the original estimation of $\sim 72 \%$ by Zhang et al. (2020). This difference implied the impacts of different selection of source signatures in these two studies. Also, we have apportioned the source of $\mathrm{NH}_{3}$ with corrected $\delta^{15} \mathrm{~N}-\mathrm{NH}_{3}$ values of both inventories and samples by adding $15 \%$ o to the corresponding passive sampler measurement data. The results showed that $66 \%$ of $\mathrm{NH}_{3}$ was from non-agricultural emissions (Fig. 3b). This attribution may be more reliable due to the updated inventory. The different contributions between Figs. $3 \mathrm{a}$ and $\mathrm{b}$ for each source, in particular for fertilizers, industry, and vehicles, indicated the uncertainty introduced by the low $\delta^{15} \mathrm{~N}-\mathrm{NH}_{3}$ bias of passive samplers.
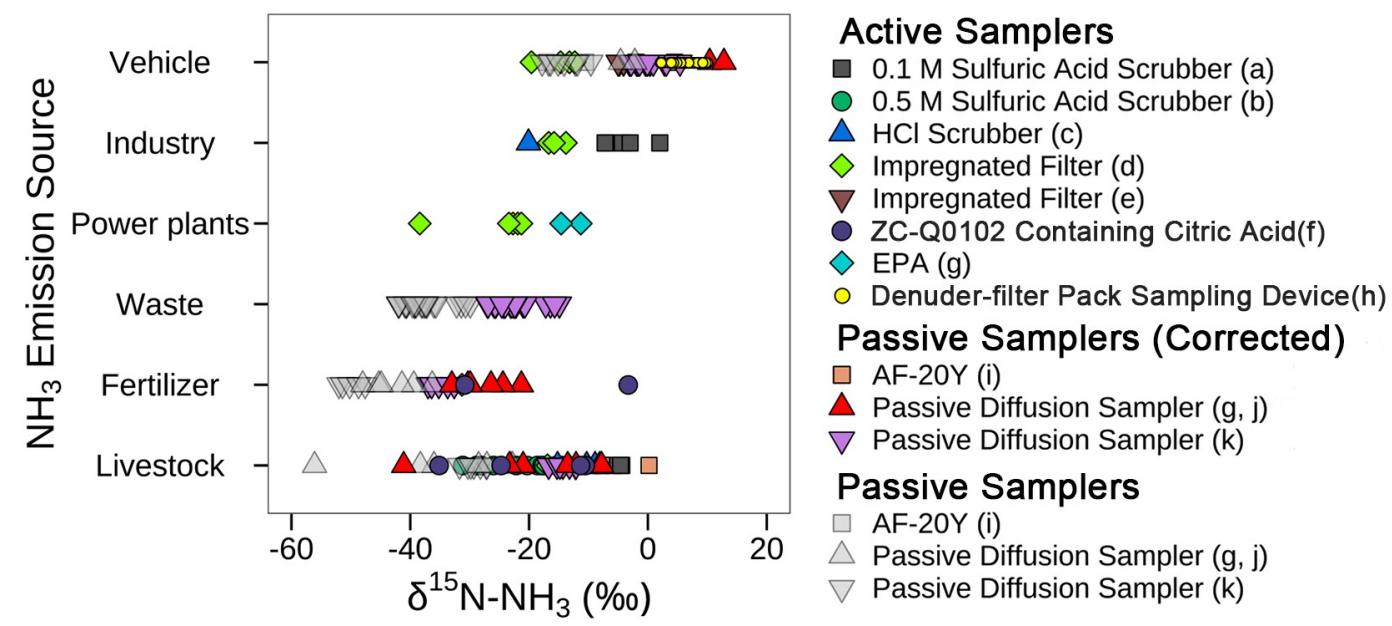

Fig. 2. The nitrogen isotopic composition of ammonia characterized at various endmembers. Recent reported isotopic signatures from traffic plumes, fertilizer and livestock (Ti et al., 2018; Kawashima, 2019; Walters et al., 2020a) were updated based on the previous summary by Walters and Hastings (2018). Note that the field sampling was conducted by different collection methods (legend) and is grouped by passive against active samplers (symbols with colors). To correct the low bias of passive data (gray symbols), 15\%o was added to the original values and is shown as corrected (symbols with colors) accordingly. Symbols with the same color and shape represent a series of observations during the same campaign. Data sources: (a) Freyer (1978); (b) Hristov et al. (2009); (c) Heaton (1987); (d) Savard et al. (2017); (e) Smirnoff et al. (2012); (f) Ti et al. (2018); (g) Felix et al. (2013); (h) Walters et al. (2020b); (i) Kawashima (2019); (j) Felix et al. (2014); (k) Chang et al. (2016).

(a) Without correction

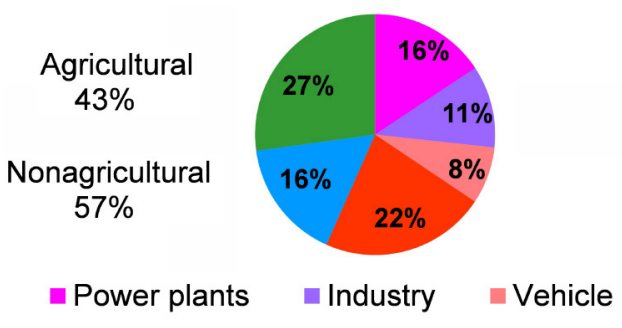

(b) With correction

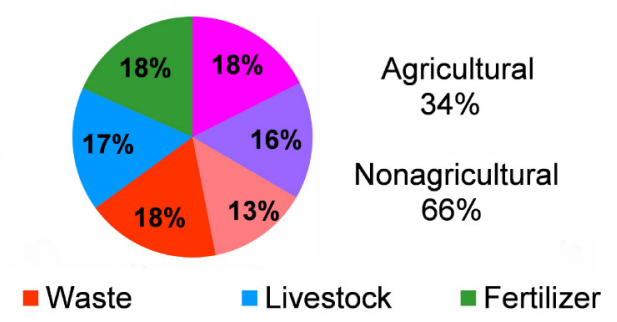

Fig. 3. Source apportionment of atmospheric ammonia in urban Beijing based on isotopic inventory (a) without and (b) with correction for the passive collection bias in characterizing nitrogen isotopic composition of ammonia, as shown in Fig. 2. The nitrogen isotopic values of $-18.2 \%$ (corrected) and $-33.2 \%$ (original) were selected as input for ambient ammonia samples. The original isotope data of $-33.2 \%$ were the annual mean values observed between March 2016 and March 2017 by Zhang et al. (2020). 


\section{Outlook}

It is important to note that tropospheric $\mathrm{NH}_{3}$ concentrations can be reduced through tight control measures; else they will continue to increase. Constraining $\mathrm{NH}_{3}$ sources utilizing stable nitrogen isotopes can aid policymakers to draft a mitigation strategy for $\mathrm{NH}_{3}$ emissions, but this method depends on an accurate characterization of $\delta^{15} \mathrm{~N}-\mathrm{NH}_{3}$ from both source and receptor sites. While the isotopic inventory has significant impacts on the source apportionment, a verified collection technique is warranted to improve the source inventory of $\delta^{15} \mathrm{~N}_{-} \mathrm{NH}_{3}$. Due to the different lifetime of $\mathrm{NH}_{3}$ and $\mathrm{NH}_{4}{ }^{+}$in the atmosphere, the sources of $\mathrm{NH}_{3}$ and $\mathrm{NH}_{4}{ }^{+}$at a given site may also be different. Thus, a better knowledge of nitrogen fractionation via atmospheric processes, e.g., gas-to-particle conversion, also helps in source apportionment of atmospheric $\mathrm{NH}_{3}$ and $\mathrm{NH}_{4}{ }^{+}$. To address this concern, the concurrent determination of different chemical speciation (i.e., $\delta^{15} \mathrm{~N}-\mathrm{NH}{ }_{3}$ and $\delta^{15} \mathrm{~N}-$ $\mathrm{NH}_{4}^{+}$) is highly needed.

Acknowledgements. This study was supported by the National Key Research and Development Program of China (Grant No. 2017YFC0210100), National Research Program for Key Issues in Air Pollution Control (Grant No. DQGG0208) and the National Natural Science Foundation of China (Grant No. 41405144). WWW acknowledges support from the Atmospheric and Geospaces Sciences U.S. National Science Foundation (Grant No. AGS 1351932). We acknowledge the U.K. Department for Environment Food \& Rural Affairs (uk-air.defra.gov.uk) as the source of the UK ammonia data (C) Crown 2020 copyright Defra via uk-air.defra.gov.uk, licenced under the Open Government Licence). (C) Crown copyright 2020 and reproduced by permission of the Controller of HMSO and the Queen's Printer for Scotland.

\section{REFERENCES}

Adon, M., and Coauthors, 2010: Long term measurements of sulfur dioxide, nitrogen dioxide, ammonia, nitric acid and ozone in Africa using passive samplers. Atmospheric Chemistry and Physics, 10, 7467-7487, https://doi.org/10.5194/acp-10-7467-2010.

An, Z. S., and Coauthors, 2019: Severe haze in northern China: A synergy of anthropogenic emissions and atmospheric processes. Proceedings of the National Academy of Sciences of the United States of America, 116, 8657-8666, https://doi.org/10.1073/pnas. 1900125116

Bouwman, A. F., D. S. Lee, W. A. H. Asman, F. J. Dentener, K. W. van der Hoek, and J. G. J. Olivier, 1997: A global high-resolution emission inventory for ammonia. Global Biogeochemical Cycles, 11, 561-587, https://doi.org/10.1029/97GB02266.

Chang, Y. H., X. J. Liu, C. R. Deng, A. J. Dore, and G. S. Zhuang, 2016: Source apportionment of atmospheric ammonia before, during, and after the 2014 APEC summit in Beijing using stable nitrogen isotope signatures. Atmospheric Chemistry and Physics, 16, 11635-11647, https://doi.org/10.5194/acp-16-11635-2016.

Chang, Y. H., Z. Zou, Y. L. Zhang, C. R. Deng, J. L. Hu, Z. H. Shi, A. J. Dore, and J. L. Collett Jr, 2019: Assessing contributions of agricultural and nonagricultural emissions to atmospheric ammonia in a Chinese megacity. Environ. Sci. Technol., 53, 1822-1833, https://doi.org/10.1021/acs.est.8b05984.

Felix, J. D., E. M. Elliott, T. J. Gish, L. L. McConnell, and S. L. Shaw, 2013: Characterizing the isotopic composition of atmospheric ammonia emission sources using passive samplers and a combined oxidation-bacterial denitrifier approach. Rapid Communications in Mass Spectrometry, 27, 2239-2246, https://doi.org/10.1002/rcm.6679.

Felix, J. D., E. M. Elliott, T. Gish, R. Maghirang, L. Cambal, and J. Clougherty, 2014: Examining the transport of ammonia emissions across landscapes using nitrogen isotope ratios. Atmos. Environ., 95, 563-570, https://doi.org/10.1016/j.atmosenv.2014.06.061.

Freyer, H. D., 1978: Seasonal trends of $\mathrm{NH}_{4}{ }^{+}$and $\mathrm{NO}_{3}{ }^{-}$nitrogen isotope composition in rain collected at Jülich, Germany. Tellus, 30, 83-92, https://doi.org/10.3402/tellusa.v30i1.10319.

Heaton, T. H. E., 1987: ${ }^{15} \mathrm{~N}^{14} \mathrm{~N}$ ratios of nitrate and ammonium in rain at Pretoria, South Africa. Atmos. Environ., 21, 843-852, https://doi.org/10.1016/0004-6981(87)90080-1.

Höpfner, M., and Coauthors, 2019: Ammonium nitrate particles formed in upper troposphere from ground ammonia sources during Asian monsoons. Nature Geoscience, 12, 608-612, https://doi.org/10.1038/s41561-019-0385-8.

Hristov, A. N., S. Zaman, M. Vander Pol, P. Ndegwa, L. Campbell, and S. Silva, 2009: Nitrogen losses from dairy manure estimated through nitrogen mass balance and chemical markers. Journal of Environmental Quality, 38, 2438-2448, https://doi.org/10.2134/jeq2009.0057.

Huang, X., and Coauthors, 2012: A high-resolution ammonia emission inventory in China. Global Biogeochemical Cycles, 26, GB1030, https://doi.org/10.1029/2011GB004161.

Ianniello, A., F. Spataro, G. Esposito, I. Allegrini, E. Rantica, M. P. Ancora, M. Hu, and T. Zhu, 2010: Occurrence of gas phase ammonia in the area of Beijing (China). Atmospheric Chemistry and Physics, 10, 9487-9503, https://doi.org/10.5194/acp-10-9487-2010.

Kawashima, H., 2019: Seasonal trends of the stable nitrogen isotope ratio in particulate nitrogen compounds and their gaseous precursors in Akita, Japan. Tellus B: Chemical and Physical Meteorology, 71, 1627846, https://doi.org/10.1080/16000889.2019.1627846.

Kendall, C., E. M. Elliott, and S. D. Wankel, 2007: Tracing anthropogenic inputs of nitrogen to ecosystems. Stable Isotopes in Ecology and Environmental Science, 2nd ed., R. Michener and K. Lajtha, Eds., Blackwell Publishing Ltd, https://doi.org/10.1002/ 9780470691854.ch12.

Li, Y., and Coauthors, 2016: Increasing importance of deposition of reduced nitrogen in the United States. Proceedings of the National Academy of Sciences of the United States of America, 113, 5874-5879, https://doi.org/10.1073/pnas.1525736113. 
Liu, D. W., Y. T. Fang, Y. Tu, and Y. P. Pan, 2014: Chemical method for nitrogen isotopic analysis of ammonium at natural abundance. Analytical Chemistry, 86, 3787-3792, https://doi.org/10.1021/ac403756u.

Liu, M. X., and Coauthors, 2018: Rapid $\mathrm{SO}_{2}$ emission reductions significantly increase tropospheric ammonia concentrations over the North China Plain. Atmospheric Chemistry and Physics, 18, 17933-17943, https://doi.org/10.5194/acp-18-17933-2018.

Liu, M. X., and Coauthors, 2019: Ammonia emission control in China would mitigate haze pollution and nitrogen deposition, but worsen acid rain. Proceedings of the National Academy of Sciences of the United States of America, 116, 7760-7765, https://doi.org/10.1073/pnas.1814880116.

Martin, N. A., and Coauthors, 2019: Validation of ammonia diffusive and pumped samplers in a controlled atmosphere test facility using traceable Primary Standard Gas Mixtures. Atmos. Environ., 199, 453-462, https://doi.org/10.1016/j.atmosenv.2018.11.038.

Meng, Z. Y., W. L. Lin, X. M. Jiang, P. Yan, Y. Wang, Y. M. Zhang, X. F. Jia, and X. L. Yu, 2011: Characteristics of atmospheric ammonia over Beijing, China. Atmospheric Chemistry and Physics, 11, 6139-6151, https://doi.org/10.5194/acp-11-6139-2011.

Pan, Y. P., and Coauthors, 2016: Fossil fuel combustion-related emissions dominate atmospheric ammonia sources during severe haze episodes: Evidence from ${ }^{15} \mathrm{~N}$-stable isotope in size-resolved aerosol ammonium. Environ. Sci. Technol., 50, 8049-8056, https://doi.org/10.1021/acs.est.6b00634.

Pan, Y. P., and Coauthors, 2018: Identifying ammonia hotspots in China using a national observation network. Environ. Sci. Technol., 52, 3926-3934, https://doi.org/10.1021/acs.est.7b05235.

Pan, Y. P., and Coauthors, 2020a: Systematic low bias of passive samplers in characterizing nitrogen isotopic composition of atmospheric ammonia. Atmospheric Research, 243, 105018, https://doi.org/10.1016/j.atmosres.2020.105018.

Pan, Y. P., and Coauthors, 2020b: Ammonia should be considered in field experiments mimicking nitrogen deposition. Atmos. Ocean. Sci. Lett., 13, 48-251, https://doi.org/10.1080/16742834.2020.1733919.

Pan, Y. P., Y. S. Wang, G. Q. Tang, and D. Wu, 2012: Wet and dry deposition of atmospheric nitrogen at ten sites in Northern China. Atmospheric Chemistry and Physics, 12, 6515-6535, https://doi.org/10.5194/acp-12-6515-2012.

Puchalski, M. A., M. E. Sather, J. T. Walker, C. M. B. Lehmann, D. A. Gay, J. Mathew, and W. P. Robarge, 2011: Passive ammonia monitoring in the United States: Comparing three different sampling devices. Journal of Environmental Monitoring, 13, 3156-3167, https://doi.org/10.1039/C1EM10553A.

Savard, M. M., A. Cole, A. Smirnoff, and R. Vet, 2017: $\delta^{15} \mathrm{~N}$ values of atmospheric N species simultaneously collected using sectorbased samplers distant from sources--Isotopic inheritance and fractionation. Atmos. Environ., 162, 11-22, https://doi.org/10.1016/ j.atmosenv.2017.05.010.

Shephard, M. W., and Coauthors, 2020: Ammonia measurements from space with the Cross-track Infrared Sounder: Characteristics and applications. Atmospheric Chemistry and Physics, 20, 2277-2302, https://doi.org/10.5194/acp-20-2277-2020.

Smirnoff, A., M. M. Savard, R. Vet, and M. C. Simard, 2012: Nitrogen and triple oxygen isotopes in near-road air samples using chemical conversion and thermal decomposition. Rapid Communications in Mass Spectrometry, 26, 2791-2804, https://doi.org/10.1002/ rcm.6406.

Sun, K., and Coauthors, 2017: Vehicle emissions as an important urban ammonia source in the United States and China. Environ. Sci. Technol., 51, 2472-2481, https://doi.org/10.1021/acs.est.6b02805.

Teng, X. L., Q. J. Hu, L. M. Zhang, J. J. Qi, J. H. Shi, H. Xie, H. W. Gao, and X. H. Yao, 2017: Identification of major sources of atmospheric $\mathrm{NH}_{3}$ in an urban environment in northern China during wintertime. Environ. Sci. Technol., 51, 6839-6848, https://doi.org/ 10.1021/acs.est.7b00328.

Ti, C. P., B. Gao, Y. X. Luo, X. Wang, S. W. Wang, and X. Y. Yan, 2018: Isotopic characterization of $\mathrm{NH}_{\mathrm{x}}-\mathrm{N}$ in deposition and major emission sources. Biogeochemistry, 138, 85-102, https://doi.org/10.1007/s10533-018-0432-3.

von Bobrutzki, K., and Coauthors, 2010: Field inter-comparison of eleven atmospheric ammonia measurement techniques. Atmospheric Measurement Techniques, 3, 91-112, https://doi.org/10.5194/amt-3-91-2010.

Walters, W. W., and M. G. Hastings, 2018: Collection of ammonia for high time-resolved nitrogen isotopic characterization utilizing an acid-coated honeycomb denuder. Analytical Chemistry, 90, 8051-8057, https://doi.org/10.1021/acs.analchem.8b01007.

Walters, W. W., L. L. Song, J. J. Chai, Y. T. Fang, N. Colombi, and M. G. Hastings, 2020a: Constraining ammonia emissions in vehicle plumes utilizing nitrogen stable isotopes. Atmospheric Chemistry and Physics Discussions, https://doi.org/10.5194/acp-2020-188.

Walters, W. W., L. L. Song, J. J. Chai, Y. T. Fang, N. Colombi, and M. G. Hastings, 2020b: Constraining ammonia emissions in vehicle plumes utilizing nitrogen stable isotopes. Atmospheric Chemistry and Physics Discussions, https://doi.org/10.5194/acp-2020-188.

Wang, G. H., and Coauthors, 2016: Persistent sulfate formation from London Fog to Chinese haze. Proceedings of the National Academy of Sciences of the United States of America, 113, 13630-13635, https://doi.org/10.1073/pnas.1616540113.

Wang, S. S., and Coauthors, 2015: Atmospheric ammonia and its impacts on regional air quality over the megacity of Shanghai, China. Scientific Reports, 5, 15842, https://doi.org/10.1038/srep15842.

Wang, Y. S., W. P. Yu, Y. P. Pan, and D. Wu, 2012: Acid Neutralization of precipitation in Northern China. Journal of the Air \& Waste Management Association, 62, 204-211, https://doi.org/10.1080/10473289.2011.640761.

Warner, J. X., R. R. Dickerson, Z. Wei, L. L. Strow, Y. Wang, and Q. Liang, 2017: Increased atmospheric ammonia over the world's major agricultural areas detected from space. Geophys. Res. Lett., 44, 2875-2884, https://doi.org/10.1002/2016GL072305.

Zhang, Y. Y., K. B. Benedict, A. H. Tang, Y. L. Sun, Y. T. Fang, and X. J. Liu, 2020: Persistent nonagricultural and periodic agricultural emissions dominate sources of ammonia in urban Beijing: Evidence from ${ }^{15} \mathrm{~N}$ stable isotope in vertical profiles. Environ. Sci. Technol., 54, 102-109, https://doi.org/10.1021/acs.est.9b05741. 